OPEN ACCESS

Edited by:

Amit Kumar Tyagi,

The University of Texas MD Anderson

Cancer Center, USA

Reviewed by:

Louis Coroller,

Université de Bretagne Occidentale

France

Fatih Ozogul,

Cukurova University, Turkey

*Correspondence:

Jennifer Ronholm

jennifer.ronholm@hc-sc.gc.ca

Specialty section:

This article was submitted to

Food Microbiology,

a section of the journal

Frontiers in Microbiology

Received: 26 January 2016

Accepted: 07 March 2016

Published: 22 March 2016

Citation:

Ronholm J, Lau F and Banerjee SK

(2016) Emerging Seafood

Preservation Techniques to Extend

Freshness and Minimize Vibrio

Contamination.

Front. Microbiol. 7:350

doi: 10.3389/fmicb.2016.00350

\section{Emerging Seafood Preservation Techniques to Extend Freshness and Minimize Vibrio Contamination}

\author{
Jennifer Ronholm ${ }^{1 *}$, Fiona Lau ${ }^{1,2}$ and Swapan K. Banerjee ${ }^{1}$ \\ ${ }^{1}$ Microbiology Research Division, Bureau of Microbial Hazards, Food Directorate, Health Products and Food Branch, Health \\ Canada, Ottawa, ON, Canada, ${ }^{2}$ University of Ottawa, Ottawa, ON, Canada
}

Globally, the popularity of seafood consumption is increasing exponentially. To meet the demands of a growing market, the seafood industry has increasingly been innovating ways to keep their products fresh and safe while increasing production. Marine environments harbor several species of indigenous microorganisms, some of which, including Vibrio spp., may be harmful to humans, and all of which are part of the natural microbiota of the seafood. After harvest, seafood products are often shipped over large geographic distances, sometimes for prolonged periods, during which the food must stay fresh and pathogen proliferation must be minimized. Upon arrival there is often a strong desire, arising from both culinary and nutritional considerations, to consume seafood products raw, or minimally cooked. This supply chain along with popular preferences have increased challenges for the seafood industry. This has resulted in a desire to develop methodologies that reduce pathogenic and spoilage organisms in seafood items to comply with regulations and result in minimal changes to the taste, texture, and nutritional content of the final product. This mini-review discusses and compares several emerging technologies, such as treatment with plant derived natural compounds, phage lysis, high-pressure processing, and irradiation for their ability to control pathogenic vibrios, limit the growth of spoilage organisms, and keep the desired organoleptic properties of the seafood product intact.

Keywords: Vibrio, seafood, shelf-life extension, irradiation, phage treatment, ozone treatment

\section{INTRODUCTION}

Global seafood consumption has increased dramatically in the last few decades from an average of $9.9 \mathrm{~kg}$ per capita in the $1960 \mathrm{~s}$ to $18.9 \mathrm{~kg}$ in 2010 , this trend is expected to continue, putting additional pressure on our aquaculture systems (FAO, 2014). Post-harvest seafood harbors microorganisms acquired from the harvest site and some of these organisms can facilitate spoilage or be hazardous to human health. Seafood refers to mollusks (oysters, clams, and mussels), finfish, marine mammals, fish eggs (roe), and crustaceans (shrimp, crab, and lobster); however, some commodities are inherently more risky than others. As an example, there were 122 cases of Vibrio parahaemolyticus infections reported in western Canada between 2001 and 2006, 66.7\% of infections were acquired through the consumption of raw oysters (Khaira and Galanis, 2007). Oysters pose the highest risk of infection for two reasons: oysters feed by filtering large volumes of seawater, during this process they may accumulate and concentrate pathogenic microorganisms 
that are naturally present in the water and for culinary reasons they are generally consumed without cooking. Therefore, oysters are a primary focus of novel intervention strategies.

Since the 1970s the bacterial pathogens primarily associated with illness due to seafood consumption have been from the genus Vibrio, specifically the species $V$. cholerae, $V$. parahaemolyticus, and V. vulnificus (DePaola et al., 2010). These vibrios occur naturally in marine environments, and with the exception of toxigenic $V$. cholerae $\mathrm{O} 1$, are not associated with fecal pollution (DePaola et al., 2010). Infection with $V$. vulnificus is rare; for example, in Canada only $2 \%$ of Vibrio infections (7 of 330 cases) were due to $V$. vulnificus between 2007 and 2013 (NESP, 2016). However, V. vulnificus infections can manifest as acute gastroenteritis, necrotizing wound infections, or invasive septicemia and have a mortality rate of approximately 50\%, making it the leading cause of seafood associated mortality (Mead, 1999). Infection occurs mainly in individuals with pre-existing conditions who have consumed raw oysters (Nishibuchi and DePaola, 2005). While case fatality is lower, $V$. parahaemolyticus is the leading cause of acute gastroenteritis associated with the consumption of seafood; V. parahaemolyticus was responsible for $60 \%$ of Vibrio infections in the USA in 2013 (CDC, 2015), and 57\% of Vibrio infections in Canada during 2007-2013 (NESP, 2016).

Several recent epidemiological studies have shown that general measures aimed at preventing environmental contamination and temperature control can be very effective at increasing shelf-life and reducing the prevalence of seafood-borne infections. For example, from 1999 to 2001, in response to a record number $(12,318)$ of cases of $V$. parahaemolyticus in 1998, Japan released new regulations concerning how commercial enterprises handle seafood, including: the use of sterile or artificial seawater for washing, soaking, preserving, and cooling seafood after it has been boiled, maintaining fresh seafood at or below a temperature of $10^{\circ} \mathrm{C}$, not consuming raw seafood with a $\mathrm{V}$. parahaemolyticus level above $100 \mathrm{MPN} / \mathrm{g}$, and consuming food within $2 \mathrm{~h}$ of being removed from refrigeration (Hara-Kudo and Kumagai, 2014). These control measures reduced infections rates by 99 -fold the year after they were introduced (Hara-Kudo and Kumagai, 2014). In 2003, California instituted a regulation indicating that oysters to be consumed raw could not be harvested from the Gulf of Mexico during April 1-October 1, corresponding to the warmer high-risk season, in an effort to lower the incidence of $V$. vulnificus infection, which varied between 0 and 6 cases annually. After 2003 no further infections of $V$. vulnificus have been recorded in that state (Vugia et al., 2013).

The ultimate goal is to safely consume raw seafood, particularly oysters, from all harvest grounds year round. Therefore, novel and non-thermal technologies that are able to reduce pathogens, extend shelf-life, and preserve the nutritional and culinary benefits of the raw product, are strongly desired. Here, we review emerging technologies in terms of efficiency of treatment, mechanism of action, effects on the bacterial cell (Figure 1), effects on the food, and overall safety of use (Table 1).

\section{OZONE TREATMENT}

Ozone treatment, either by gaseous or dissolved forms, is among one of the most powerful oxidizing and food contact sanitizing treatments approved by the U.S. Food and Drug Administration (FDA). Ozone treatments oxidize various cellular components leading to membrane leakage and eventually cell death (Figure 1), it has high biocidal activity, requires short contact times, and can take place at the aquaculture level or on the final product. As an example of the former, applying $0.07 \mathrm{mg} / \mathrm{L}$ of ozone directly to seawater at shrimp hatcheries has been shown to allow the survival of shrimp, but eliminate pathogenic vibrios (Blogoslawski and Stewart, 2011). Studies on seafood spoilage are generally assessed based on several metrics including bacterial levels (CFU/g), the levels of gases produced from seafood breakdown such as total volatile basic nitrogen (TVB-N), trimethylamine nitrogen (TMA-N), total volatile acid (TVA), and ranking the food on fit-for-consumption scales based on sight and smell (Ordóñez et al., 2000; Arkoudelos et al., 2007; Pantazi et al., 2008). These methods are complementary, but each has a high-level of consensus when determining if a seafood product is spoiled (Pantazi et al., 2008). Most research in this area has focused on the ability of ozone to extend shelf-life. Ozone treatment of freshly harvested shrimp was evaluated for the ability to extend shelf-life using bacterial levels, TVB-N, TMA-N, and sensory characteristics as the evaluation criteria. After washing shrimp in ozone treated water for 1 min shelf-life was extended by 1.75 days (Okpala, 2014). Trout filets treated with ozone for two hours, were assessed by (TVB-N) measures, and found to have a shelf-life of 6 days, as compared to 4 days for untreated filets (Dehkordi and Zokaie, 2010). Shucked and vacuum-packaged mussels were assessed by spoilage bacteria levels, TVB-N, and sensory evaluation and were shown to have a shelf-life of 12 days after ozone treatment, as opposed to 9 days without treatment (Manousaridis et al., 2005).

Ozonised water can be used to produce slurry ice; however, the results of using this product to extend the shelf-life of seafood appear to depend on the nature of the seafood product. While, one study found that storage on ozonised slurry ice extended the shelf-life of sardines from 15 to 19 days (Campos et al., 2005), a more recent study found no increase in shelf-life of Tiger grouper, a reef fish, after storage on ozonised slurry ice (Karim et al., 2015).

\section{NATURAL ORGANIC TREATMENTS}

Adding essential oils, tea polyphenols, and organic acids to seafood products has been suggested to extend shelf-life, limit pathogen proliferation, and maintain a synthetic preservative free marketing status. Essential oils such as thyme, oregano, rosemary, turmeric, and shallots have been shown to decrease the levels of non-pathogenic spoilage bacteria in seafood, when used in concentrations as low as $0.05 \mathrm{mg} / \mathrm{mL}$ (Harpaz et al., 2003; Pezeshk et al., 2011; Li et al., 2012). A variety of polyphenols including catechins, epigallocatechin gallate (EGCG), epigallocatechin, 


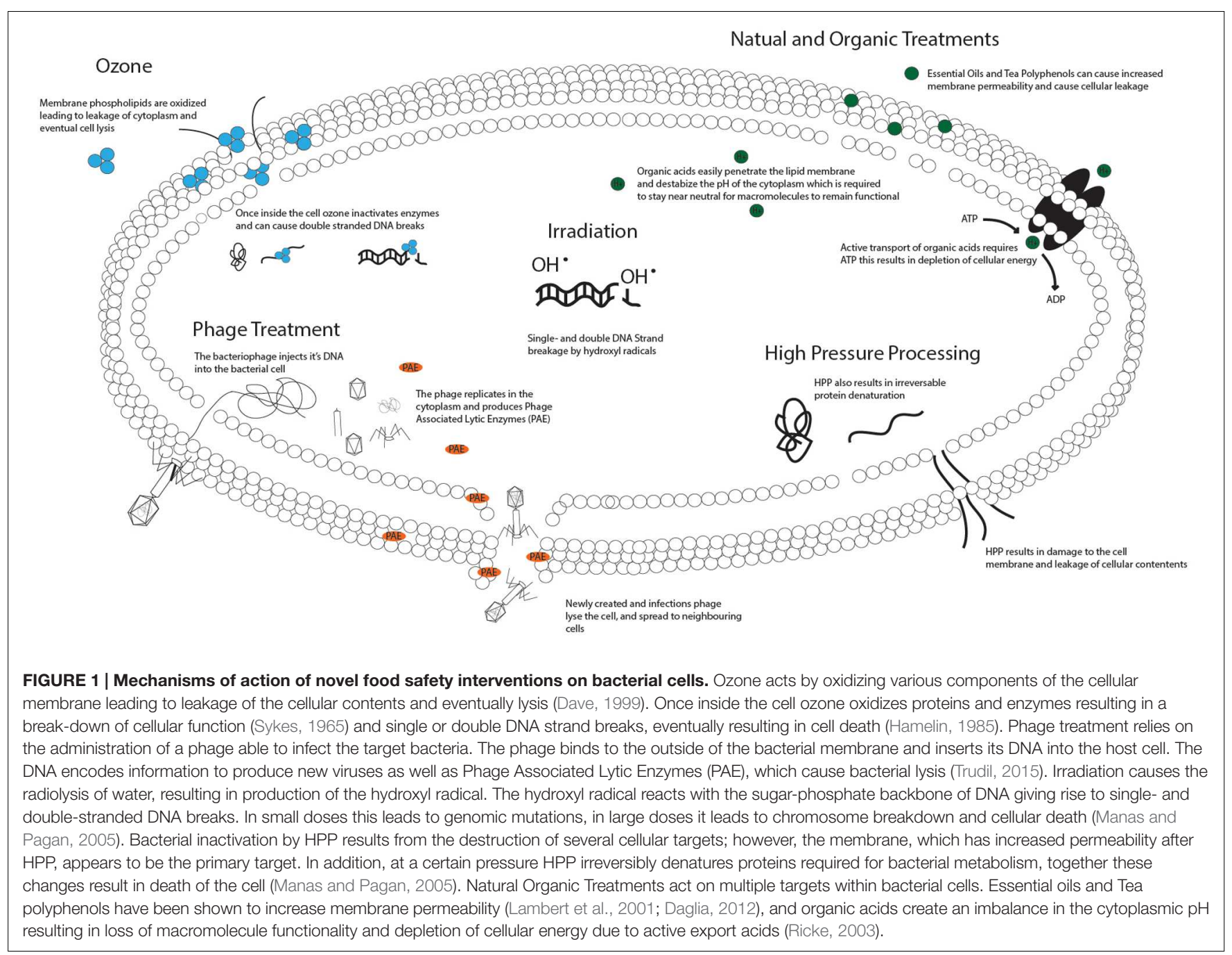

epicatechin gallate, and epicatechin, can be extracted from tea and have been shown to have antioxidant and antimicrobial properties (Fujiki, 1999). For example, immersing shrimp in a $0.01 \%$ catechin solution for only 15 min slowed the growth of spoilage bacteria, reduced the Enterobacteriaceae count, and had other quality enriching effects on the shrimp such as reducing lipid oxidation and melanosis (Nirmal and Benjakul, 2009). Dipping treatments of dried-seasoned jumbo squid in a mixed tea phenol solution also showed a protective effect against bacterial spoilage, moisture loss, oxidation of lipids, and degradation of lipids (Dong et al., 2013). Tea phenol treatment has also been shown to have a synergistic effect when combined with ozone treatment to extend shelf-life, and reduce nucleotide breakdown and lipid oxidation (Feng et al., 2012). Organic acids such as citric acid $(300 \mathrm{mg} / \mathrm{mL})$ and lactic acid $(150 \mathrm{mg} / \mathrm{mL})$ have been shown to reduce growth of spoilage organisms in freshly shucked oyster sample; in addition, dipping treatments of oysters in each of these organic acids showed a reduction of potentially pathogenic $V$. vulnificus below the detection level of $1.0 \mathrm{log} / \mathrm{g}$ from an initial artificially inoculated concentration of $6.0 \mathrm{log} / \mathrm{g}$ (Mahmoud, 2013).

\section{PHAGE TREATMENT}

Two different phage groups have shown promise in controlling populations of $V$. parahaemolyticus in raw oysters: a Siphoviridae phage pVp-1 (Jun et al., 2014), and VPpla phage isolated from $V$. parahaemolyticus (Peng et al., 2013). Depuration is a control process in which molluscs are held in potable water that has been treated with chlorine, ozone, or UV light, for a few hours before consumption to reduce their bacterial loads through the process of filter feeding. While this method is very effective in reducing coliform counts, unless it is carried out at low temperature and for a period of days, depuration is generally not effective against vibrios (Phuvasate et al., 2012). However, depuration in the presence of the phage VPpla was able to reduce $V$. parahaemolyticus concentrations by 2.35-2.76 log CFU/g over a period of $36 \mathrm{~h}$ at $16^{\circ} \mathrm{C}$ (Rong et al., 2014). The phage $\mathrm{pVp}-1$ was investigated for its ability to eliminate $V$. parahaemolyticus contamination as applied as both a bath immersion and directly to contaminated oyster meat. Both application strategies resulted in decreases in $V$. parahaemolyticus population, bath immersion treatment reduced the bacterial counts from $8.9 \times 10^{6} \mathrm{CFU} / \mathrm{g}$ 
to $14 \mathrm{CFU} / \mathrm{g}$ after $72 \mathrm{~h}$; however, direct application of phage to contaminated meat almost eliminated contamination within $12 \mathrm{~h}$ at $18^{\circ} \mathrm{C}$, with $1.4 \times 10^{6} \mathrm{CFU} / \mathrm{g}$ in the control and just $1.9 \mathrm{CFU} / \mathrm{g}$ in the treated samples (Jun et al., 2014). However, shellfish presents several challenges for phage treatment, the large and uneven surface area, when applied on in-shell oysters, limits contact time between phage particles and bacterial targets (Guenther et al., 2009).

\section{HIGH PRESSURE PROCESSING}

High pressure processing (HPP), is commercially used at a range between 200 and $600 \mathrm{MPa}$, as an alternative to thermal processing (Considine et al., 2008). HPP treatment as short as 1-2 min on oysters increases shelf-life by as many as 11 days, by lowering the overall bacterial load and in the process kills the oyster causing the adductor muscle to release and making shucking easier (He et al., 2002). Particular attention has been paid to the ability of HPP to reduce $V$. parahaemolyticus and $V$. vulnificus in oysters. At harvest, the density of $V$. parahaemolyticus is generally less than $10^{3} \mathrm{MPN} / \mathrm{g}$; however, pathogen levels rapidly increase to $>10^{6} \mathrm{MPN} / \mathrm{g}$ if the storage temperature is not properly controlled (Gooch et al., 2001), and these levels are hazardous to human health. Considerable differences in pressure resistance between $V$. parahaemolyticus strains have been reported (Kural, 2008) making guidelines for effective HPP treatments to remove $V$. parahaemolyticus difficult. Differences of $1 \rightarrow 7 \log$ reductions in $V$. parahaemolyticus have been reported, based on several variables including: pressure level, suspension medium, processing time, processing temperature, and whether a whole shelled oyster or just meat tissue is assayed (Calik et al., 2006; Kural, 2008; Phuvasate and Su, 2015). While increasing pressure and processing time increase the log-reductions observed for $V$. parahaemolyticus, HPP appears to be more effective against $V$. parahaemolyticus when carried out at lower temperatures (Phuvasate and $\mathrm{Su}, 2015$ ). If the temperature is lowered to $1.5^{\circ} \mathrm{C}$ from $20^{\circ} \mathrm{C}$, the processing time can be lowered from 10 to $5 \mathrm{~min}$ and the pressure can be lowered to $250 \mathrm{MPa}$ from $300 \mathrm{MPa}$ without a loss in log reduction (Phuvasate and Su, 2015). Storage temperatures of seafood prior to HPP do not appear to affect resistance of $V$. parahaemolyticus to HPP; however, cold storage may increase the resistance of $V$. vulnificus to HPP treatment by increasing the percentage of polyunsaturated fatty acid in the cell membrane (Ye et al., 2013). Post-HPP cold storage has been shown to cause additional reductions in cell number after HPP-treatment, which may be occurring due to inhibition of recovery of sub-lethally injured cells (Ye et al., 2013). Despite its advantages, HPP also leads to meat becoming more opaque (Murchie et al., 2005), and results in the cooked

TABLE 1 | Principle, mechanisms of resistance, primary hazards, and the impact on food of each emerging technology.

\begin{tabular}{|c|c|c|c|c|}
\hline & Principle & $\begin{array}{l}\text { Impact on organoleptic seafood } \\
\text { qualities }\end{array}$ & $\begin{array}{l}\text { Mechanisms of bacterial } \\
\text { resistance }\end{array}$ & Primary hazards \\
\hline Ozone & $\begin{array}{l}\text { Oxidizes biologically active } \\
\text { macromolecules }\end{array}$ & $\begin{aligned} & \text { - } \text { Neutral* } \\
& \text { - Does not oxidize seafood lipids } \\
& \text { (Chawla et al., 2007) }\end{aligned}$ & - None reported* & $\begin{array}{l}\text { - GRAS } \\
\text { - Residues of treatment } \\
\text { include } \mathrm{CO}_{2} \text { and } \mathrm{H}_{2} \mathrm{O} \\
\text { (Gonclaves, 2009) }\end{array}$ \\
\hline Phage treatment & $\begin{array}{l}\text { Bacteriophages infect and lyse } \\
\text { bacterial cells }\end{array}$ & - Neutral* & $\begin{array}{l}\text { - Blocking phage receptors } \\
\text { - Production of extracellular } \\
\text { matrix } \\
\text { - Preventing DNA entry } \\
\text { (Labrie et al., 2010) }\end{array}$ & $\begin{array}{l}\text { - GRAS } \\
\text { - Naturally found in most food } \\
\quad \text { products (Jun et al., 2014) }\end{array}$ \\
\hline $\begin{array}{l}\text { Natural organic } \\
\text { treatments }\end{array}$ & $\begin{array}{l}\text { Natural organic treatments } \\
\text { change parameters of the food } \\
\text { making it difficult for microbial } \\
\text { survival and proliferation }\end{array}$ & - Variable & - Variable & $\begin{array}{l}\text { - Not Hazardous } \\
\text { - Naturally occurs in foods }\end{array}$ \\
\hline $\begin{array}{l}\text { High pressure } \\
\text { processing }\end{array}$ & $\begin{array}{l}\text { HPP damages cellular } \\
\text { membranes, changes cell } \\
\text { morphology, and denatures } \\
\text { proteins }\end{array}$ & $\begin{array}{l}\text { - Negative } \\
\text { - Oyster meat becomes whiter and } \\
\text { more opaque with increased } \\
\text { pressure (Murchie et al., 2005) } \\
\text { - Results in the cooked } \\
\text { appearance fish } \\
\text { (Master et al., 2000) }\end{array}$ & $\begin{array}{l}\text { - Bacterial strains have high } \\
\text { variability in resistance, the } \\
\text { reasons are not understood* }\end{array}$ & $\begin{array}{l}\text { - GRAS } \\
\text { - Leaves no residue }\end{array}$ \\
\hline Irradiation & $\begin{array}{l}\text { Directly damages DNA of living } \\
\text { organisms }\end{array}$ & $\begin{array}{l}\text { - Neutral } \\
\text { - No change in the sensory } \\
\text { characteristics of oyster meat } \\
\text { (Andrews et al., 2003; } \\
\text { Jakabi et al., 2003; } \\
\text { Song et al., 2009) }\end{array}$ & $\begin{array}{l}\text { - Variable } \\
\text { - Low resistance in food borne } \\
\text { bacteria }\end{array}$ & $\begin{array}{l}\text { - GRAS } \\
\text { - Leaves no residue } \\
\text { - Approved by several } \\
\text { governments including the } \\
\text { FDA, UK, and France } \\
\text { (Wang et al., 2015) } \\
\text { - Can be used on frozen food } \\
\text { without the requirement of } \\
\text { thawing }\end{array}$ \\
\hline
\end{tabular}

*Indicates that additional research is required in this area. GRAS - generally recognized as safe. 
appearance of several types of fish (Master et al., 2000), two factors that may limit its acceptance by consumers (Table 1).

\section{IRRADIATION}

Irradiation of food products has become an emerging technology with promising features to enhance the safety and shelf-life of many different food types. Irradiation offers several unique characteristics including direct inactivation of organisms in frozen foods (Farkas, 1998). The use of gamma irradiation and more recently X-rays to eliminate pathogenic strains of bacteria such as vibrios in live oysters is becoming a popular alternative to thermal treatment (Grodner and Andrews, 1996; Farkas, 1998; Andrews et al., 2003; Jakabi et al., 2003; Mahmoud, 2009).

Gamma irradiation dose levels from 0.5-3.0 kGy have been tested on live oysters with studies showing that the maximum dose of $3.0 \mathrm{kGy}$ did not kill the oysters or affect any of their sensory attributes. Although, reductions of 6-log $V$. parahaemolyticus were observed when dosage levels as low as $1.0 \mathrm{kGy}$ were used (Jakabi et al., 2003). X-ray treatments on laboratory inoculated $V$. parahaemolyticus ready to eat shrimp products treated with $0.1-4 \mathrm{kGy} \mathrm{X}$-ray levels showed a 6-log reduction in CFUs at $3 \mathrm{kGy}$ (Mahmoud, 2009). To achieve a 6$\log$ reduction of $V$. vulnificus in oysters $1.0 \mathrm{kGy}$ was required for half shell oysters and $3.0 \mathrm{kGy}$ for whole shell oysters (Mahmoud, 2009).

\section{REFERENCES}

Andrews, L., Jahncke, M., and Mallikarjunan, K. (2003). Low dose gamma irradiation to reduce pathogenic vibrios in live oysters (Crassostrea virginica). J. Aquat. Food Prod. Technol. 12, 71-82. doi: 10.1300/J030v12n03_07

Arkoudelos, J., Stamatis, N., and Samaras, F. (2007). Quality attributes of farmed eel (Anguilla anguilla) stored under air, vacuum and modified atmosphere packaging at 0 degrees C. Food Microbiol. 24, 728-735. doi: 10.1016/j.fm.2007.03.008

Blogoslawski, W. J., and Stewart, M. E. (2011). Some ozone applications in seafood. Ozone Sci. Eng. 33, 368-373. doi: 10.1080/01919512.2011.602006

Calik, H., Morrissey, M. T., Reno, P. W., and An, H. (2006). Effect of high-pressure processing on Vibrio parahaemolyticus strains in pure culture and pacific oysters. J. Food Sci. 67, 1506-1510. doi: 10.1111/j.1365-2621.2002.tb10313.x

Campos, C. A., Rodriguez, O., Losada, V., Aubourg, S. P., and Barros-Velazquez, J. (2005). Effects of storage in ozonised slurry ice on the sensory and microbial quality of sardine (Sardina pilchardus). Int. J. Food Microbiol. 103, 121-130.

CDC (2015). Foodborne Diseases Active Surveillance Network (FoodNet): FoodNet Surveillance Report for 2013 (Final Report). Atlanta, GA: U.S. Department of Health and Human Services, CDC.

Chawla, A., Bell, J., and Marlene, E. J. (2007). Optimization of ozonated water treatment of wild-caught and mechanically peeled shrimp meat. J. Aquat. Food Process. Technol. 16, 41-56. doi: 10.1300/J030v16n02_05

Considine, K. M., Kelly, A. L., Fitzgerald, G. F., Hill, C., and Sleator, R. D. (2008). High-pressure processing effects on microbial food safety and food quality. FEMS Microbiol. Lett. 281, 1-9. doi: 10.1111/j.1574-6968.2008.01084.x

Daglia, M. (2012). Polyphenols as antimicrobial agents. Curr. Opin. Biotechnol. 23, 174-181. doi: 10.1016/j.copbio.2011.08.007

Dave, S. A. (1999). Efficacy of Ozone Against Salmonella Enteritidis in Aqueous Suspensions and on Poultry Meat. Master thesis, The Ohio State University, Columbus, Ohio. 26-68.

Dehkordi, B. M., and Zokaie, N. (2010). Extension of fish shelf life by ozone treatment. Int. J. Environ. Chem. Ecol. Geol. Geophys. Eng. 4, 108-110.

\section{CONCLUSION}

Here, we have presented a short overview of several novel seafood preservation interventions along with the effect they have on bacterial cells (Figure 1), seafood quality, and possible hazards (Table 1). None of the technologies reviewed here represents a hazard in the food supply. However, some have unique advantages: the effectiveness of irradiation on frozen food without the need for thawing prior to treatment, and disadvantages: the bleaching of oyster meat exposed to HPP. Based on the variability of the effectiveness of the intervention, and the effects of the intervention on the seafood product we note the importance of validation of each sanitization strategy on each seafood product prior to routine use.

\section{AUTHOR CONTRIBUTIONS}

All authors listed, have made substantial, direct and intellectual contribution to the work, and approved it for publication.

\section{FUNDING}

This study was funded from Heath Canada A-Base funding.

DePaola, A., Jones, J. L., Woods, J., Burkhardt, W., Calci, K. R., Krantz, J. A., et al. (2010). Bacterial and viral pathogens in live oysters: 2007 united states market survey. Appl. Environ. Microbiol. 76, 2754-2768. doi: 10.1128/AEM.02590-09

Dong, L., Zhu, J., Li, X., and Li, J. (2013). Effect of tea polyphenols on the physical and chemical characteristics of dried-seasoned squid (Dosidicus gigas) during storage. Food Control 31, 586-592. doi: 10.1016/j.foodcont.2012.10.014

FAO (2014) The State of World Fisheries and Aquaculture, Part I, World Review of Fisheries and Aquaculture, 3-93. Available at: http://www.fao.org/publicat ions/card/en/c/097d8007-49a4-4d65-88cd-fcaf6a969776/ [accessed January 22, 2016].

Farkas, J. (1998). Irradiation as a method for decontaminating food. Int. J. Food Microbiol. 44, 189-204. doi: 10.1016/S0168-1605(98)00132-9

Feng, L., Jiang, T., Wang, Y., and Li, J. (2012). Effects of tea polyphenol coating combined with ozone water washing on the storage quality of black sea bream (Sparus macrocephalus). Food Chem. 135, 2915-2921. doi: 10.1016/j.foodchem.2012.07.078

Fujiki, H. (1999). Two stages of caner provention with green tea. J. Cancer Res. Clin. Oncol. 125, 589-597. doi: 10.1007/s004320050321

Gonclaves, A. (2009). Ozone - an emerging technology for the seafood industry. Braz. Arch. Biol. Technol. 52, 1527-1539. doi: 10.1590/S151689132009000600025

Gooch, J. A., DePaola, A., Kaysner, C. A., and Marshall, D. L. (2001). Evaluation of two direct plating methods using nonradioactive probes for enumeration of Vibrio parahaemolyticus in oysters. Appl. Environ. Microbiol. 67, 721-724. doi: 10.1128/AEM.67.2.721-724.2001

Grodner, R. M., and Andrews, L. S. (1996). Effects of low dose gamma irradiation on the bacterial microflora of freshly picked crabmeat. AGRIS 48, 211-216.

Guenther, S., Huwyler, D., Richard, S., and Loessner, M. J. (2009). Virulent bacteriophage for efficient biocontrol of listeria monocytogenes in ready-to-eat foods. Appl. Environ. Microbiol. 75, 93-100. doi: 10.1128/AEM.01711-08

Hamelin, C. (1985). Production of single- and double- stranded breaks in plasmid DNA by ozone. Oncol. Biol. Phys. 11, 253-257. doi: 10.1016/03603016(85)90146-4 
Hara-Kudo, Y., and Kumagai, S. (2014). Impact of seafood regulations for Vibrio parahaemolyticus infection and verification by analyses of seafood contamination and infection. Epidemiol. Infect. 142, 2237-2247. doi: 10.1017/S0950268814001897

Harpaz, S., Glatman, L., Drabkin, V., and Gelman, A. (2003). Effects of herbal essential oils used to extend the shelf life of freshwater-reared Asian sea bass fish (Lates calcarifer). J. Food Prot. 66, 410-417.

He, H., Adams, R. M., Farkas, D. F., and Morrissey, M. T. (2002). Use of highpressure processing for oyster shucking and shelf-life extension. J. Food Sci. 67, 640-645. doi: 10.1111/j.1365-2621.2002.tb10652.x

Jakabi, M., Gelli, D. S., Torre, J. C. M. D., Rodas, M. A. B., Franco, B. D. G. M., Destro, M. T., et al. (2003). Inactivation by ionizing radiation of Salmonella enteritidis, Salmonella infantis, and Vibrio parahaemolyticus in oysters (Crassostrea brasiliana). J. Food Prot. 66, 1025-1029.

Jun, J. W., Kim, H. J., Yun, S. K., Chai, J. Y., and Park, S. C. (2014). Eating oysters without risk of vibriosis: application of a bacteriophage against Vibrio parahaemolyticus in oysters. Int. J. Food Microbiol. 188, 31-35. doi: 10.1016/j.ijfoodmicro.2014.07.007

Karim, N. U., Nasir, N., Arifin, B., and Ismail, M. (2015). Effect of salt and ozonizedslurry ice on the quality indices of Tiger grouper. J. Sustainab. Sci. Manag. 10, 97-102.

Khaira, G., and Galanis, E. (2007). Descriptive epidemiology of Vibrio parahaemolyticus and other Vibrio species Infections in British Columbia: 2001-2006. Can. Commnu. Dis. Rep. 33:11.

Kural, A. (2008). Conditions for a 5-log reduction of Vibrio vulnificus in oysters through high hydrostatic pressure treatment. Int. J. Food Microbiol. 122, 180187. doi: 10.1016/j.ijfoodmicro.2007.11.074

Labrie, S. J., Samson, J. E., and Moineau, S. (2010). Bacteriophage resistance mechanisms. Nat. Rev. Micribiol. 8, 317-327. doi: 10.1038/nrmicro2315

Lambert, R. J., Skandamis, P. N., Coote, P. J., and Nychas, G. J. (2001). A study of the minimum inhibitory concentration and mode of action of oregano essential oil, thymol and carvacrol. J. Appl. Microbiol. 91, 453-462.

Li, T., Li, J., Hu, W., Zhang, X., Li, X., and Zhao, J. (2012). Shelf-life extension of crucian carp (Carassius auratus) using natural preservatives during chilled storage. Food Chem. 135, 140-145. doi: 10.1016/j.foodchem.2012.04.115

Mahmoud, B. S. M. (2009). Effect of X-ray treatments on inoculated Escherichia coli O157: H7, Salmonella enterica, Shigella flexneri and Vibrio parahaemolyticus in ready-to-eat shrimp. Food Microbiol. 26, 860-864. doi: 10.1016/j.fm.2009.05.013

Mahmoud, B. S. M. (2013). Controlling Vibrio vulnificus and spoilage bacteria in fresh shucked oysters using natural antimicrobials. Lett. Appl. Microbiol. 58, 1-7. doi: 10.1111/lam.12152

Manas, P., and Pagan, R. (2005). Microbial inactivation by new technologies of food preservation. J. Appl. Microbiol. 98, 1387-1399.

Manousaridis, G., Nerantzaki, A., Paleologos, E. K., Tsiotsias, A., Savvaidis, I. N., and Kontominas, M. G. (2005). Effect of ozone on microbial, chemical and sensory attributes of shucked mussles. Food Microbiol. 22, 1-9. doi: 10.1016/j.fm.2004.06.003

Master, A. M., Stegeman, D., Kals, J., and Bartels, P. V. (2000). Effects of high pressure on colour and texture of fish. Int. J. High Pressure Res. 19, 109-115. doi: $10.1080 / 08957950008202543$

Mead, P. (1999). Food-related illness and death in the united states. Emerg. Infect. Dis. 5, 607-625. doi: 10.3201/eid0505.990502

Murchie, L. W., Cruz-Romero, M., Kerry, J. P., Linton, M., Patterson, M. F., Smiddy, M., et al. (2005). High pressure processing of shellfish: a review of microbiological and other quality aspects. Innov. Food Sci. Emerg. Technol. 6, 257-270. doi: 10.1016/j.ifset.2005.04.001

NESP (2016). National Enteric Surveillance Program (NESP), National Microbiology Laboratory, Public Health Agency of Canada. Available at: https://www.nml-ln m.gc.ca/NESP-PNSME/index-eng.htm (accessed January, 2016).

Nirmal, N. P., and Benjakul, S. (2009). Melanosis and quality changes of pacific white shrimp (Litopenaeus vannamei) treated with catechin during iced storage. J. Agric. Food Chem. 57, 3578-3586. doi: 10.1021/jf900051e
Nishibuchi, M., and DePaola, A. (2005). Foodborne Pathogens Microbiology and Molecular Biology. Norfolk: Caister Academic Press.

Okpala, C. O. R. (2014). Quality evaluation and shelf life of minimal ozone-treated Pacific white shrimp (Litopenaeus vannamei) stored on ice. J. Verbr. Lebensm. 10, 49-57. doi: 10.1007/s00003-014-0904-x

Ordóñez, J. A., López Gálvez, D. E., Fernández, M., Hierro, E., and de la Hoz, L. (2000). Microbial and physicochemical modifications of hake (Merluccius merluccius) steaks stored under carbon dioxide enriched atmospheres. J. Sci. Food Agric. 80, 1831-1840. doi: 10.1002/1097-0010(200010)80:13<1831::AIDJSFA707>3.0.CO;2-Z

Pantazi, D., Papavergou, A., Pournis, N., Kontominas, M. G., and Savvaidis, I. N. (2008). Shelf-life of chilled fresh Mediterranean swordfish (Xiphias gladius) stored under various packaging conditions: microbiological, biochemical and sensory attributes. Food Microbiol. 25, 136-143. doi: 10.1016/j.fm.2007.06.006

Peng, Y., Ding, Y. J., Lin, H., and Wang, J. X. (2013). Isolation, identification and lysis properties analysis of a Vibrio parahaemolyticus phage VPp1. Mar. Sci. 37, 96-101.

Pezeshk, S., Rezaei, M., and Hosseini, H. (2011). Effects of turmeric, shallot extracts, and their combination on quality characteristics of vacuum-packaged rainbow trout stored at $4 \pm 1{ }^{\circ}$ C. J. Food Sci. 76, M387-M391. doi: 10.1111/j.17503841.2011.02242.x

Phuvasate, S., Chen, M. H., and Su, Y. C. (2012). Reductions of Vibrio parahaemolyticus in Pacific oysters (Crassostrea gigas) by depuration at various temperatures. Food Microbiol. 31, 51-56. doi: 10.1016/j.fm.2012.02.004

Phuvasate, S., and Su, Y.-C. (2015). Efficacy of low-temperature high hydrostatic pressure processing in inactivating Vibrio parahaemolyticus in culture suspension and oyster homogenate. Int. J. Food Microbiol. 196, 11-15. doi: 10.1016/j.ijfoodmicro.2014.11.018

Ricke, S. C. (2003). Perspectives on the use of organic acids and short chain fatty acids as antimicrobials. Poult. Sci. 82, 632-639. doi: 10.1093/ps/82.4.632

Rong, R., Lin, H., Wang, J., Khan, M. N., and Li, M. (2014). Reductions of Vibrio parahaemolyticus in oysters after bacteriophage application during depuration. Aquaculture 41, 171-176. doi: 10.1016/j.aquaculture.2013.09.028

Song, H. P., Kim, B., Jung, S., Choe, J. H., Yun, H., Kim, Y. J., et al. (2009). Effect of gamma and electron beam irradiation on the survival of pathogens inoculated into salted, seasoned, and fermented oyster. Food Sci. Technol. 42, 1320-1324.

Sykes, G. (1965). Disinfection and Sterilization, 2nd Edn. London: E. \& F.N. Spon., Ltd.

Trudil, D. (2015). Phage lytic enzymess: a history. Virol. Sin. 30, 26-32. doi: 10.1007/s12250-014-3549-0

Vugia, D. J., Tabnak, F., Newton, A. E., Hernandez, M., and Griffin, P. M. (2013). Impact of 2003 state regulation on raw oyster-associated Vibrio vulnificus illnesses and deaths, California, USA. Emerg. Infect. Dis. 19, 1276-1280. doi: 10.3201/eid1908.121861

Wang, W., Li, M., and Li, Y. (2015). Intervention strategies for reducing Vibrio parahaemolyticus in seafood: a review. J. Food Sci. 80, R10-R19. doi: 10.1111/1750-3841.12727

Ye, M., Huang, Y., Gurtler, J. B., Niemira, B. A., Sites, J. E., and Chen, H. (2013). Effects of pre- or post-processing storage conditions on high-hydrostatic pressure inactivation of Vibrio parahaemolyticus and V. vulnificus in oysters. Int. J. Food Microbiol. 163, 146-152. doi: 10.1016/j.ijfoodmicro.2013.02.019

Conflict of Interest Statement: The authors declare that the research was conducted in the absence of any commercial or financial relationships that could be construed as a potential conflict of interest.

Copyright (c) 2016 Ronholm, Lau and Banerjee. This is an open-access article distributed under the terms of the Creative Commons Attribution License (CC BY). The use, distribution or reproduction in other forums is permitted, provided the original author(s) or licensor are credited and that the original publication in this journal is cited, in accordance with accepted academic practice. No use, distribution or reproduction is permitted which does not comply with these terms. 